ОСОБЛИВОСТІ САМОСТІЙНОСТІ СУЧАСНИХ СТУДЕНТІВ МАЙБУТНІХ ФАХІВЦІВ СОЦІОНОМІЧНИХ ПРОФЕСІЙ

\title{
PECULIARITIES OF MODERN STUDENTS' INDEPENDENCE FUTURE SPECIALISTS OF SOCIONOMIC PROFESSIONS
}

В статті представлено результати теоретико-прикладного дослідження самостійності як інтегративної якості особистості сучасного студента, яка полягає у здатності та потребі приймати й реалізовувати рішення з власної ініціативи і нести за них відповідальність. Встановлено, що чя якість розвивається на основі чілеспрямованої і свідомо регульованої активності суб'єкта діяльності, в тому числі і на ранніх етапах професіоналізації у виші. До змісту психологічної характеристики самостійності входять: пізнання і діяльність, вольові характеристики, рівень відповідальності, здатність до самоствердження.

у професійному навчанні сучасного сту дента, майбутнього фрахівия, самостійність проявляється в здатності суб'єкта профресійного становлення здобувати необхідні знання та набувати вмінь, фоормувати профресійно важливі якості, опановувати різні способи дій, в тому числі і в умовах невизначеності. Для виявлення рівня самостійності студентів у навчальній діяльності нами було виділено такі критерії: саморозви ток, самостійність, сила волі, самоствердження та відповідальність. Було визначено ступінь вираженості цих показників у досліджуваних студентів кожного курсу навчання

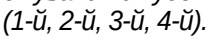

Також було визначено загальний рівень академічної успішності досліджуваних студентів кожного окремого курсу навчання. Встановлено, що найвищі показники навчально діяльності були визначені у студентів чет вертого курсу, 2 ранг - у першокурсників, найнижчі показники академічної успішності констатовано у студентів 3 курсу.

3 метою визначення зв'язків між показниками академічної успішності на різних курсах навчання студентів та параметрами самостійності було проведено кореляційний аналіз.

Дослідження показало, що самостійність сучасних студентів соціономічних профресій зростає за період навчання у виші, причому емпірично визначено прямий статистично значущий взаємозв'язок між самостійністю і рівнем академічної успішності досліджуваних Також емпірично встановлено, що в академічно успішних студентів спостерігається прямий взаємозв'язокміжпараметрами: «Відповідальність», «Самостійність», «Саморозвиток» та між показниками «Сила волі» та «Самоствердження». У студентів, яких умовно віднесли до групи відносно успішних у навчальній діяльності, взаємозв'язку між досліджуваними параметрами не виявлено. Ключові слова: самостійність, саморозви ток, сила волі, самоствердження, відповідальність, академічна успішність
The article presents the results of theoretical and applied research of independence, as an integrative quality of a modern student's personality, which means the ability and necessity to make and implement decisions on their own initiative and to be responsible for them. It is established that this quality develops on the basis of purposeful and consciously regulated activity of the person's action, including the early stages of professionalization at higher education establishments. The content of the psychological characteristics of independence includes: cognition and activity, volitional characteristics, the level of responsibility, the ability to self-affirmation.

In the professional training of a modern student future specialist, independence is manifested in the person's ability to acquire the necessary knowledge and skills, to form professionally important qualities, to master various ways of action, including the conditions of uncertainty. To identify the level of students' independence in educational activities, we have identified the following criteria: self-development, independence, willpower, self-affirmation and responsibility. The level of domination of these indicators among the research volunteers of each course (the 1st, the 2nd, the 3rd, the 4th) was determined.

The general level of academic success of the research volunteers of each individual year of study was also determined. It is established that the highest indicators of educational activity were determined among the fourth-year students, the second rank was the first-year students, the lowest indicators of academic success were demonstrated among the third-year students.

A correlation analysis was performed to determine the connection between academic performance in different years of study and the parameters of independence.

The study showed that the independence of modern students of socionomic professions increases during the period of their study at higher educational establishments and a direct statistically significant connection between independence and the level of research volunteers academic success was empirically determined. It is also empirically established that academically successful students have a direct connection between the parameters: "Responsibility", "Independence", "Self-development" and between the indicators "Willpower" and "Self-affirmation". Students, who were conditionally classified as relatively successful in academic activities, did not demonstrated the connection between these parameters.

Key words: independence, self-development, willpower, self-affirmation, responsibility, academic success
Професійний розвиток особистості відбувається задовго до початку трудової діяльності [1, с. 187]. Однак у сучасних умовах, коли ми спостерігаємо збільшення потоку інформації, майбутньому фахівцеві вже неможливо орієнтуватися лише на засвоєння сукупності професійно важливих знань, вмінь та навичок. Дуже важливо, щоб людина вміла самостійно примножувати свої знання, орієнтуватись у великому обсязі інформації, що поступає 3 навколишнього світу. До того ж самостійність необхідна для здійснення самостійних 
узагальнень, прийняття самостійних рішень і виконання самостійних дій як у процесі подолання навчальних труднощів, так і під час вирішення професійних завдань, розв'язання ускладнених ситуацій професійної діяльності.

Дослідження А.К. Маркової, Е.А. Клімова, Н.С. Пряжнікова та інших доводять, що психологічно насичена професійна діяльність виражається в абсолютній самостійності людини як суб'єкта праці. Це твердження має пряме відношення і до фахівців соціономічних професій. В.А. Кан-Калик, Л.М. Мітіна, Є.І. Рогов та інші підкреслюють відповідність самостійності найвищому рівню педагогічної творчості і називають цей рівень особистісно самостійним. Ми повністю згодні з цією думкою та вважаємо, що це положення можна віднести і щодо представників інших професій системи «людина-людина».

У той же час для розвитку творчості, креативності молодому фахівцеві важливо з самого початку надавати максимальну самостійність. Краще, якщо це буде зроблено ще на етапі професійного навчання, оскільки саме у вищому навчальному закладі закладаються основні якості фахівця, формуються необхідні компетенції. Подібну точку зору поділяють В.А. Балюк, І.Ф. Бережна [2], А.А. Вербицький, О.В. Волобуєва [6], М.І. Дьяченко, Р.І. Іванов, І.Д. Клегеріс, Т.І. Лядова, Л.І. Малихіна [4], Е.Ф. Мосін, Сердюк Л.3. [5], М.Ф. Шустваль [6], С.М. Шустваль [6], В.А. Якунін та інші. Самостійність визнається дослідниками одночасно і якістю особистості професіонала, і засобом досягнення професіоналізму.

I.C. Кон трактує самостійність як властивість особистості, яка передбачає, по-перше, незалежність, здатність самому, без підказки ззовні, приймати важливі рішення, по-друге, готовність відповідати за наслідки своїх дій і вчинків [3, с. 42]. Отже, самостійність стає якістю особистості, коли людина усвідомлено здатна робити власний вибір, приймати рішення, нести за них повну відповідальність.

Виконувати розпорядження інших легше, ніж діяти самостійно. Але в діяльності майбутнього фахівця-професіонала самостійність виходить на перший план. Саме тому метою нашого дослідження є вивчення самостійності як інтегративної професійно важливої якості сучасних студентів, майбутніх фахівців.

Метою дослідження $€$ теоретичне вивчення та емпіричне дослідження співвідношення параметрів самостійності студентів з різним рівнем академічної успішності.

Вибірку склали студенти 1-го, 2-го, 3-го, 4-го курсів, віком 18-22 роки, які обрали професії педагога та психолога і навчаються у Ізмаїльському державному гуманітарному університеті, ДВНЗ «Донбаський державний педагогічний університет» та Академії державної пенітенціарної служби.
В дослідженні використовувалися такі методи: а) теоретичні: аналіз, співставлення, узагальнення, систематизація - для вивчення теоретико-методологічних засад проблеми дослідження; б) емпіричні методи діагностики $з$ використанням наступних конкретних методик: а) тест: «Наскільки Ви самостійний»; б) тест: «Оцінка здібності до саморозвитку, самоосвіти»; в) методика визначення сили волі Р.C. Немова; г) тест: «Експрес-діагностика відповідальності» (методика В.П. Прядеін); д) тест: «Здатність до самоствердження»; методи математико-статистичної обробки результатів дослідження, зокрема кореляційний аналіз (коефіцієнт рангової кореляції Ч. Спірмена) та Н-критерій Крускала-Уолліса.

Для того, щоб виявити рівень самостійності студентів у навчальній діяльності, нами було виділено такі критерії: саморозвиток, самостійність, сила волі, самоствердження та відповідальність. Було визначено ступінь вираженості цих показників у досліджуваних студентів кожного курсу навчання (1-й, 2-й, 3-й, 4-й). Результати отриманих даних за означеними вище методиками представлено на рис 1.

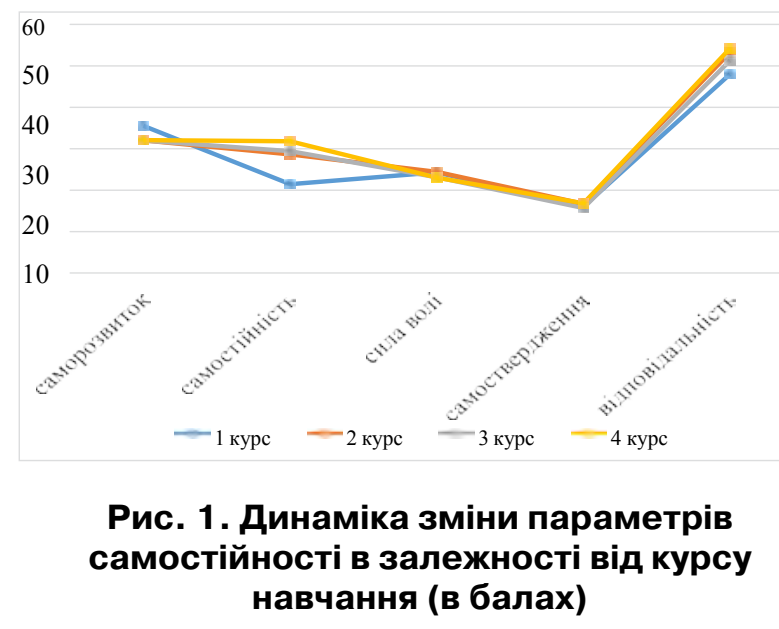

Аналіз показує, що рівень саморозвитку студентів-першокурсників дещо вищий, ніж у студентів інших досліджуваних груп (35,5 б.), але рівень саморозвитку у студентів другого та третього курсу - на однаковому рівні (32 б.). Саморозвиток у студентів четвертого курсу складає 32,1 бали.

Щодо рівня самостійності, то найвищі показники у студентів четвертого курсу 31,8 б., у третьокурсників - 29,4 б., у студентів 2 курсу - 28,6 б., та найнижчі показники констатовано у першокурсників - 21,4 б.

Сила волі у студентів 2 курсу має показники 24,4 б., у першокурсників - 24,3 б., у студентів третього курсу -т 23,1 б., четвертого 23 бали.

Що стосується показників самоствердження, то значного розбігу у досліджуваних груп не констатовано. У студентів 1 курсу 16 б., 2-го - 16,7 балів, трохи нижчі показники 
Взаємозв'язок параметрів самостійності з навчальною успішністю (в балах)

Таблиця 1

\begin{tabular}{|c|c|c|c|c|c|}
\hline \multirow[b]{2}{*}{ Параметри } & \multicolumn{5}{|c|}{ Академічна успішність } \\
\hline & 1 курс & 2 курс & 3 курс & 4 курс & $\begin{array}{c}\text { Загальна } \\
\text { вибірка }\end{array}$ \\
\hline Саморозвиток & 0,430 & 0,347 & 0,315 & 0,312 & $0,322^{* *}$ \\
\hline Самостійність & 0,154 & 0,228 & 0,375 & 0,394 & $0,288^{\star \star}$ \\
\hline Сила волі & 0,263 & $-0,110$ & 0,060 & 0,071 & 0,044 \\
\hline Самоствердження & 0,181 & 0,075 & $-0,007$ & 0,015 & 0,083 \\
\hline Відповідальність & $0,488^{*}$ & 0,349 & $0,447^{*}$ & 0,018 & $0,352^{\star \star}$ \\
\hline
\end{tabular}

* - статистично достовірна $(\mathrm{p} \leq 0,05)$;

** - статистично достовірна $(\mathrm{p} \leq 0,01)$.

були у третьокурсників - 15,8 б., у студентів 4-го курсу - 16,8 б.

За параметром відповідальності найвищий показник діагностовано у студентів 4 курсу 54,2 б., у студентів 2 курсу - 53,2 б., у третьокурсників - 51,3 б., та у першокурсників - 48 б.

Наступним етапом нашого дослідження було вивчення загального рівня академічної успішності досліджуваних студентів кожного окремого курсу навчання.

Найвищі показники навчальної діяльності були визначені у студентів четвертого курсу (загальний середній бал у двадцяти досліджуваних був 83,5). У студентів першого курсу показники середнього балу академічної успішності були дещо нижчі, ніж у студентів четвертого курсу 80,28. На другому курсі середній навчальний бал $-79,22$. Та найнижчі показники були на третьому курсі - 76,17.

3 метою визначення зв'язків між показниками академічної успішності студентів на різних курсах навчання з параметрами самостійності було проведено кореляційний аналіз, підраховано коефіцієнт рангової кореляції Ч. Спірмена.

У результатівикористання методу кореляції встановлено статистично достовірний прямий взаємозв'язок між параметрами “Саморозвиток» та «академічна успішність» у студентів загальної вибірки ( $r=0,322^{\star \star} ; p=\leq 0,01$; $\mathrm{n}=80$ ). Це означає, що з підвищенням рівня саморозвитку академічна успішність покращується.

Також встановлений статистично достовірний прямий взаємозв'язок між параметрами «самостійність» та академічною успішністю студентів загальної вибірки $\left(r=0,288^{* *}\right.$; $\mathrm{p}=\leq 0,01 ; \mathrm{n}=80)$. Отже, це свідчить про те, що з підвищенням рівня самостійності покращується навчальна академічна успішність.

Розглядаючи параметр «відповідальність», окрім статистично значущого прямого взаємозв'язку з академічною успішністю загальної вибірки $\left(r=0,352^{\star \star} ; p=\leq 0,01 ; n=80\right)$, також можна помітити, що $є$ статистично значущий прямий взаємозв'язок параметру «відповідальність» 3 академічною успішністю сту- дентів-першокурсників ( $r=0,488^{\star} ; p=\leq 0,05$; $\mathrm{n}=20)$ та у студентів 3 курсу $\left(r=0,447^{*}\right.$; $p=\leq 0,05 ; n=20)$. Це свідчить про те, що з підвищенням рівня відповідальності академічна успішність покращується не тільки у загальної вибірки, а й конкретно у студентів 1-го та 3-го курсів.

Щодо параметрів «сила волі та самоствердження», то статистично значущого взаємозв'язку з академічною успішністю виявлено не було. Результати дослідження означених параметрів представлено на рис. 2.

Таким чином, можна зауважити, що параметр «Саморозвиток» змінюється залежно від курсу навчання. Так, у першокурсників ми констатували високий рівень саморозвитку (48,85 б.), у студентів другого курсу показники цього параметру зменшуються до 35,60 б. , а на третьому $(38,65$ б.) та четвертому $(38,906)$. курсах знов зростають.

Показники параметру «Самостійність» також змінюються, вони зростають. Так, у студентів 1 курсу середній бал - 26,30, другого курсу - 39,95, третього - 44,08, та у старшокурсників цей показник $є$ найвищим - 51,68 б. 3 цього можна зауважити, що самостійність студентів поступово зростає.

Показники параметру «Сила волі» у першокурсників складають 41,5 бали, у студентів 2 курсу - зростають до 43,15 б., у третьокурсників - 38,80 б., а у старшокурсників - 38,55.

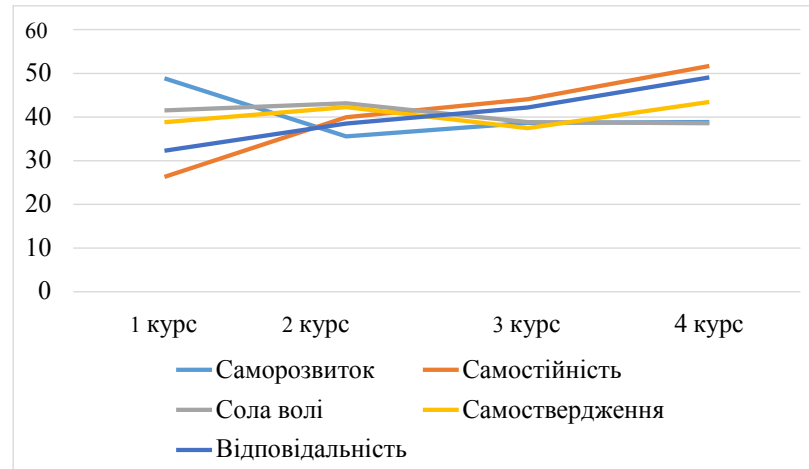

Рис. 2. Динаміка параметрів самостійності 3 академічною успішністю залежно від курсу навчання (в рангах) 
Статистичний аналіз зміни параметрів самостійності у досліджуваних студентів

Таблиця 2 протягом часу навчанні у виші (в балах)

\begin{tabular}{|c|c|c|c|c|c|c|}
\hline \multirow{3}{*}{ Параметри } & \multicolumn{4}{|c|}{ Академічна успішність } & \multirow{3}{*}{$\mathbf{H}$} & \multirow{3}{*}{$\mathbf{P}$} \\
\hline & 1 курс & 2 курс & З курс & 4 курс & & \\
\hline & $\begin{array}{c}\text { Me } \\
\text { (P25, P75) }\end{array}$ & $\begin{array}{c}\text { Me } \\
\text { (P25, P75) }\end{array}$ & $\begin{array}{c}\mathrm{Me} \\
\text { (P25, P75) }\end{array}$ & $\begin{array}{c}\text { Me } \\
\text { (P25, P75) }\end{array}$ & & \\
\hline Саморозвиток & $35(30,2 ; 41)$ & $30(28 ; 36,7)$ & $31,5(29 ; 35,7)$ & $33,5(28,5 ; 36)$ & 7,71 & 0,024 \\
\hline Самостійність & $25(20,28)$ & $29(22,5 ; 33,7)$ & $30(26,5 ; 34)$ & $32(28,5 ; 34)$ & 12,71 & 0,005 \\
\hline Сила волі & $22,5(18,2 ; 29,7)$ & $25(19,5 ; 27,7)$ & $24,5(17 ; 29,5$ & $21,5(18 ; 30)$ & 0,54 & 0,908 \\
\hline Самоствердження & $16(13 ; 19,7)$ & $16(14,5 ; 18,7)$ & $16(13,2 ; 18,7)$ & $16,5(14,5 ; 19,5)$ & 0,89 & 0,826 \\
\hline Відповідальність & $47(40,2 ; 56,7)$ & $50(46 ; 55,7)$ & $51(47,2 ; 58,7)$ & $53(49,2 ; 60,7)$ & 6,49 & 0,039 \\
\hline
\end{tabular}

Показники по параметру «Самоствердження» мають такі дані: у першокурсників 38,80 б., у студентів 2-го курсу - 42,28 б., 3-го 37,48 б., а у старшокурсників - 43,45 балів.

Показники за параметром «Відповідальність» також поступово підвищуються. Так, у першокурсників - 32,28 б., у студентів 2-го курсу - 38,50 б., 3-го - 42,15 б., а у старшокурсників - 49,08 балів.

Для визначення статистично достовірних відмінностей між показниками використали Н-критерій Крускала-Уолліса. Цей критерій використовується для оцінки відмінностей між трьома або більше експериментальними умовами (або популяціями) з використанням порядкових даних зі схеми незалежних вимірювань. Тест Краскела-Уолліса аналогічний тесту Манна-Уітні, однак критерій МаннаУітні обмежений порівнянням лише двох вибірок, тоді як критерій Краскела-Уолліса використовується для порівняння трьох або більше вибірок. У нашому експерименті порівнювалися показники 4 груп досліджуваних за 5 параметрами (див. табл. 2).

Аналізуючи дані, наведені в таблиці 2, можна зауважити, що за параметром «Саморозвиток» було визначено статистично значущі відмінності ( $P=0,024)$. Це свідчить про те, що показники цього параметру змінюються і тісно взаємопов'язані з показниками академічної успішності на різних курсах навчання.

Також можна помітити що з підвищенням рівня академічної успішності покращується рівень самостійності $(P=0,005)$. Так, у студентів 1 курсу він складає 25 б., 2-го курсу - вже 29 б., 3-го курсу - 30 б., 4-го - 32 б.

За параметром «Відповідальність» також $€$ статистично значущі відмінності $(P=0,039)$. у таблиці 2 ми бачимо, що відповідальність збільшується з підвищенням рівня академічної успішності залежно від курсу навчання. Показники відповідальності: у студентів 1 курсу 47 б., 2-го - 50, 3-го - 51, у студентів-старшокурсників 53 б.

Щодо параметрів «Сила волі» та «Самоствердження» статистично значущих відмінносте не виявлено.
Для визначення взаємозв'язку параметрів самостійності з академічною успішністю було поділено загальну вибірку, що складала 80 досліджуваних на успішних на відносно успішних студентів. Більшість наших досліджуваних мають високі показники в навчальній діяльності та вчаться виключно на «добре» та «відмінно». Таких студентів - 62 чол., що склали 78,5\% від загальної кількості досліджуваних. Решту студентів ми умовно віднесли до групи відносно успішних. Її склали 18 чоловік, що становить 21,5\% від загальної вибірки.

Встановлено статистично достовірний прямий взаємозв'язок між параметрами «Саморозвиток» та «Відповідальність» у студентів з високою академічною успішністю $\left(r=0,329^{*}\right.$; $\mathrm{p}=\leq 0,05 ; \mathrm{n}=59$ ). Також визначено прямий взаємозв'язок між параметрами «Самостійність» та «Відповідальність» $\left(r=0,322^{*}\right.$; $\mathrm{p}=\leq 0,05 ; \mathrm{n}=59$ ).

Щодо параметру «Самоствердження» було встановлено прямий взаємозв'язок з параметром «Сила волі» $\left(r=0,326^{\star} ; p=\leq 0,05 ; n=59\right)$. Більше статистично значущих взаємозв'язків у академічно успішних студентів не було.

Статистично значущого взаємозв'язку за параметром «Самостійність» у студентів групи відносно успішних у навчальній діяльності не визначено.

Таким чином, можно зробити висновок того, що у академічно успішних студентів спостерігається прямий взаємозв'язок між параметрами: «Відповідальність», «Самостійність», «Саморозвиток» та між показниками «Сила волі» та «Самоствердження». У студентів, яких ми умовно віднесли до групи відносно успішних у навчальній діяльності, взаємозв'язку між досліджуваними параметрами немає.

Таким чином, у результаті теоретико-емпіричного дослідження було визначено, що самостійність - це інтегративна якість особистості, яка полягає у здатності та потребі приймати й реалізовувати рішення 3 власної ініціативи і нести за них відповідальність. Вона розвивається на основі цілеспрямованої і свідомо регульованої активності суб'єкта діяльності, в тому числі і на ранніх етапах про- 
фесіоналізації у виші. До змісту психологічної характеристики самостійності входять: пізнання і діяльність, вольові характеристики, рівень відповідальності, здатність до самоствердження.

Дослідження показало, що самостійність сучасних студентів соціономічних професій зростає за період навчання у виші, причому емпірично визначено прямий статистично значущий взаємозв'язок між самостійністю і рівнем академічної успішності досліджуваних. Встановлено, що академічно успішні студенти мають вищі показники за параметрами: самостійність, саморозвиток та відповідальність.

\section{ЛІТЕРАТУРА:}

1. Асранасьєва Н.Є., Світлична Н.О., Остополець І.Ю. Табачник І.Г. Особливості професійної мотивації на різних етапах професіогенезу. Тео- рія і практика сучасної психології. 2019. № 5. Т. 2. C. 181-187.

2. Бережная И.Ф. Педагогическое проєктирование индивидуальной траектории профессионального развития будущего специалиста: монограсрия. Воронеж. 2012. 220 с.

3. Кон І.С. Психология самостоятельности. Знание - сила. 1985. № 7. С. 42-44.

4. Малихіна Л.І. Рівень розвитку пізнавального інтересу студентів як фрактор їх самостійності і пізнавальної активності. Сучасні педагогічні технології у вищих закладах освіти. 2001. Ч. 2. С. 77-79.

5. Сердюк Л.3. Самотворення особистості як цілісний самодетермінований френомен. Актуальні проблеми психології. 2015. Т. 7. Вип. 38. C. 422-431.

6. Шустваль М.Ф., Шустваль С.М., Лядова Т.І., Волобуєва О.В. Формування пізнавальної самостійності студентів у контексті Болонського процесу. Медична освіта. 2013. № 3. С. 125-128. 